Arch. Tierz., Dummerstorf 46 (2003) 4, 357-376

${ }^{1}$ Department of Animal Production, Faculty of Agriculture, Zagazig University, Zagazig, Egypt

${ }^{2}$ Department of Animal Wealth, Institute of Efficient Productivity, Zagazig University, Egypt

FAYEZ M. MARAI ${ }^{1}$ and A. A. RASHWAN ${ }^{2}$

\title{
Rabbits behaviour under modern commercial production conditions - a review
}

\begin{abstract}
Recently, much work has been done to record the diurnal peak of does receptivity. It was found that the highest was in the morning and before allowing suckling. Such studies suggested that mating should be achieved in the morning or before suckling to avoid the negative effect of the circadian peak of prolactin on receptivity that occur around 15.00 to $19.00 \mathrm{~h}$ and after each suckling. Some cases of pseudo-pregnancy might be prevented by double mating; the second mating should be within at most five hours after the first, since mating later than this would have no effect. Total parturition time would be 10-14 minutes for a large litter and 5-7 minutes for an average litter, although parturition could be induced to allow prompt attention to does with poor maternal instinct and to those kindle for the first time kindling and to avoid situations such as: kindling at night or in cold weather and/or to avoid the variability in gestation periods (29 to 34 days). Mother-litter separation during night can influence species specific nursing behaviour and may lead to lower weaning weights of pups. Applying good management programs, as well as, change of place, gentle handling of the stressed dams, correcting nutritional deficiencies and inadequate drinking water and provision of adequate amount of straw, may well eliminate stress, correct behavioural disorders and certain types of maternal anomalies which appear to be not under the control of hormonal or genetic factors. Welfare for caged rabbits can be improved by feeding the animals in the afternoon rather than in the morning. Aggressive behaviour was greater in rabbits on nipple drinkers than in those on troughs. In conclusion, better understanding of rabbits natural behaviour under the different conditions, maintains optimal production compatible with welfare demands.

Below, description of rabbits behaviour and its relation with modern commercial production conditions, were discussed.
\end{abstract}

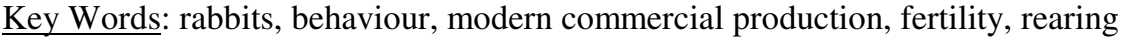

\section{Zusammenfassung}

Titel der Arbeit: Kaninchenverhalten unter gewerbsmäßigen Haltungsbedingungen- eine Übersicht

Die Studie beinhaltet Aussagen über das Verhalten von Hauskaninchen unter modernen Haltungsbedingungen. Sie setzt sich damit auseinander, welche Bedingungen verhaltensgerecht sind bzw. wie am Verhalten der Tiere erkennbar ist, ob ein gewähltes Haltungssystem als artgerecht angesehen werden kann. Das Kaninchenverhalten hängt sowohl von genetischen Faktoren als auch erworbenen Erfahrungen ab, wobei die Reaktion der Hauskaninchen auf externe oder interne Einflüsse sehr stark denen der Wildkaninchen ähnelt. Unter diesem Aspekt werden Erwartungen an die Umwelt, das Fortpflanzungsverhalten, Rezeptionsbereitschaft und Paarungsverhalten, Pseudoträchtigkeit, Geburt und Säugeverhalten, Jungtieraufzucht und mütterliches Anomalverhalten sowie das Fress- und Trinkverhalten neugeborener und adulter Tiere diskutiert.

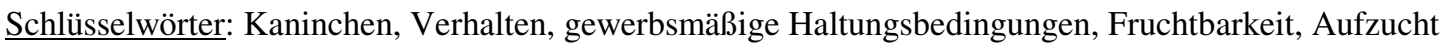

\section{Introduction}

Behaviour is either innate or acquired and depends on both genetic characteristics and previous experience and include animals action and/or reaction to a change in external or internal environment (FERRANTE et al., 1992). However, the domestic rabbit behaviour is still much like that of the wild rabbit (LEBAS et al., 1986), since many of 
the behavioural events which have been reported for wild rabbits are observed in domestic rabbits (STOUFFLET and CAILLOL, 1988). This necessitates to put in mind when we deal with rabbits that they are originally terrestrial, herbivore, coprophagous, crepuscular or nocturnal and territorial.

Welfare is a condition of the animal itself and it means that rabbits should be healthy and thrifty. This necessitates providing the rabbits freedom from thirst, hunger and malnutrition, discomfort and inadequate shelter, prevention of pain, injury and distress rapid diagnosis and treatment of injury and disease and allow them freedom to display normal patterns of behaviour free from fear (MORISSE and MAURICE, 1994). In this respect, evaluation of rabbits welfare has to consider behaviour, as well as, physiological variables. Regarding behaviour pawing on the cage floor or gnawing may be used as indicators of stress, although they may be considered normal behaviours (MORISSE and MAURICE, 1997). Feeding activity (FINZI et al., 1996), social and maternal behaviour (VERGA et al., 1978; LEHMAN, 1987, 1991; VERGA, 1997; MORISSE, 1999) may be used as indicators of acute stress due to transportation handling practices. In other words, many of the welfare questions for individual animal species, cannot be answered without more behavioural research and comprehension of the social, physical and environmental demands of such animals.

Maintaining optimal productivity compatible with increasingly stringent welfare demands, requires better understanding of rabbits natural behaviour. In other words, more understanding of patterns of rabbit behaviour and their influence on productive and reproductive performances would help in development of new managerial techniques. These techniques can be applied to maintain and breed rabbits in a manner compatible with modern commercial interests and welfare demands.

The present article aimed to discuss the behaviour of rabbits under modern commercial production conditions. Rabbit behaviour in the present article is categorized according to the different operations conducted in the modern commercial rabbit production and beginning with rabbit olfactory communication.

\section{Olfactory Communication}

Olfactory communications depend on odour and some tactile cues. Rabbits utilize olfactory communication signals for establishing and maintaining a secure territory, group status and associations and identification of mates, young, danger and reproductive status. Such trait also serves in group housing to reduce aggression and maintain population numbers by restraining indiscriminate breeding and domination of strangers within the respective territories. In addition, in an established doe and litter group, the doe's odour guides and groups the young. However, the odour substance is not present in sexually immature does.

Odour substances are a complex array of odours composed of secretions of sebaceous and sudoriferous glands found under the chin (submandibular glands), lining the rectum (anal glands) and lateral to the urogenital-anal line (inguinal glands) (GOODRICH and MYKYTOWYCZ, 1972). The glands are larger in high social status and in low density populations during the breeding season (HARKNESS, 1988). Odour contains various fractions of hydrocarbons, proteins, carbohydrates, esters, waxes, fatty acids (acetic and isovaleric), tryglycerides and steroids, with major differences in composition of the secretions of the various glands and minor variations from individual to individual and from group to group. These individual and group 
variations are due to sex, age, reproductive condition and social status effects, probably mediated to some degree by androgen levels.

The submandibular (or submittal) and anal secretions are commonly employed, along with piles of faeces and urine sprays, in territorial and individual markings. The inguinal scent serves more as a marker of young rabbits and sexual partners. Chinmarking of does by bucks is a common behaviour, especially following coitus and in new surroundings (HEATH, 1972). The waxy secretion of the submandibular gland is deposited by chinning, predominately by males within their own territory on vertical or irregular surfaces as trees, grass, branches, burrow entrances, cages, feeders, waterers, young, mates and dung hills. Horizontal surfaces are marked by dung hills and urine. These territorial olfactory marking of glandular secretions, faeces and urine provide the margins of a secured territory for the group (HARKNESS, 1988).

The rabbit in a new cage explores it and then marks it with its smell. The more strange odours in the cage, the longer this task will take (LEBAS et al., 1986).

\section{Reproductive Behaviour}

Mammalian reproduction starts with mating behaviour and terminates when the young are weaned. Between these two events, there are complex chain of behavioural phenomena which are critical for the survival of the young.

\section{Receptivity of the female}

MORET (1980) observed that female sexual behaviour (acceptance of mating) appears long before the ability to ovulate and bear litters, which is regarded as prepuberty play, but not as a sign of puberty. Does are considered to be in oestrus more or less permanently (can stay in heat for several days), since the female rabbit does not have an oestrous cycle with regular periods of heat during which ovulation occurs spontaneously. Ovulation occurs only after mating. However, a female rabbit is considered to be in heat when she accepts and in dioestrus when she refuses service. A doe in heat assumes a characteristic pose called lordosis, with the back arched downwards and hindquarters raised, while a doe in dioestrus tends to crouch in a corner of the cage or exhibit aggression towards the buck (LEBAS et al., 1986).

CHALLIS et al. (1974) and NICOSIA et al. (1975) reported that the highest levels of sexual activity are noticed on days 1, 2 and 5 post-partum in primparous and on days 1 and 9 post-partum in multiparous does. Other authors indicate that doe sexual heat is greater on the first day than on the tenth day post-partum (PERRIER et al., 1982; SURDEAU et al., 1982). The maximum values of the sexual activity index on day 1 post-partum are probably associated with high levels of estradiol-17 $\beta$ produced by the largest anthral follicles from day 30 of pregnancy (CHALLIS et al., 1974; NICOSIA et al., 1975). However, sexual behaviour appeared to be influenced by lactation probably via prolactin concentration, since BEYER and RIVAUD (1969) observed a post-partum oestrus lasting about $48 \mathrm{~h}$ in most rabbits, and only 50\% sporadically displayed sexual behaviour between the third day of lactation and weaning in New Zealand White (NZW) and Californian (Cal) rabbits. UBILLA and REBOLLAR (1994) also found a long low sexual receptivity interval (from day 3 to 24 post-partum) in lactating rabbits with 7-10 pups/litter. A decrease in the ovulation rate could be expected during these post-partum days and hormone induction of oestrus appears to be necessary. HAMMOND and MARSHALL (1925) stated that the lactating doe 
consistently refused the buck after the $12^{\text {th }}$ day of lactation, while YASHINE et al. (1967) observed occasional sexual behaviour in lactating rabbits. Apparently progesterone secretion is low during lactation in the rabbit (HILLARD et al., 1968). Lactational anoestrus is more likely to relate to the low secretion of estrogen by the ovaries due to inhibition of gonadotropin secretion (BEYER and RIVAUD, 1969).

Characteristics of the genitalia, i.e. colour and turgidity are strongly related to sexual behaviour. Red colour is related to high levels of acceptance (97.5\%), i.e. a red vulva is considered a strong indication, though not a proof of oestrus, while white colour is associated with a high percentage of rejection (80\%). Turgidity improves the acceptance rate for all colours of vulva.

CUDNOVSKII (1957) and BEREPUBO et al. (1993) claimed that the natural receptivity cycle of a doe is 5 to 7 days, with a duration as short as 6 to 7 hours during some times of the year. However, DIAZ et al. (1988) indicated that during the postpartum period, there are no periodical cycles in the colour and turgidity of the vulva or in behaviour. The same authors also claimed that sexual behaviour is not homogeneous from days 1 to 11 post-portum.

The pattern of female sexual behaviour varies, during pregnancy. Female receptivity decreases during early pregnancy, but it is augmented during few days before parturition (MORET, 1980; STOUFFLET and CAILLOL, 1988). In other words, progesterone seems to inhibit sexual receptivity (BEYER and McDONALD, 1973) and blocks sexual behaviour (ELSAESSER, 1980; HUDSON et al., 1990), while estrogen is necessary for receptivity in the female rabbit, since KLEIN, 1956) found that administration of estrogen induced oestrous behaviour in pregnant rabbits. During the late stage of pregnancy, the increase in sexual behaviour observed is probably a result of low level of progesterone production combined with the increase in output of estrogen by the growing follicles. LEBAS et al. (1986) clarified that the pregnant female refused to mate in most mammals, but a pregnant doe rabbit generally accept mating throughout the gestation period more in the second half of pregnancy.

The males display 2 important behaviours: nuzzling and mounting, and remain inactive for a short time during female pregnancy. A quantitative difference in male behaviour is also noted in the presence of receptive and non-receptive females only in the first part of pregnancy (STOUFFLET and CAILLOL, 1988). HEATH (1972) noted that domestic bucks marked a variety of inanimate objects when the female was nonreceptive, while MYKYTOWYCZ (1968) described a territorial function for chinmarking, in the wild male rabbit. At the same time, the pregnant does display 2 main behaviours: flattening in the corner of the cage and/or circling away from the male on introduction into the male's cage (STOUFFLET and CAILLOL, 1988). During the second part of pregnancy, no differences were noted between sexual behaviour of receptive and non-receptive females. This could be due to a reduced mobility of the female at the end of pregnancy. Mounting the male was only observed post-partum and seemed to be inhibited during pregnancy as described by BEYER and McDONALD (1973). BEYER and RIVAUD (1969) observed a decrease in sexual activity (mating and mounting behaviour) in both NZW and Cal rabbits during late pregnancy.

Reduction in doe's receptivity, may occur as a result of overweight, poor nutrition, bad feed, incorrect lighting program, suckling a large litter, health problems, moulting, etc. (PLA, 1984 ; TORRES LOZNO et al., 1987 ; DIAZ et al., 1988). 
Recently, much work has been done to stimulate the does receptivity without the use of exogenous hormones such as pregnant mare's serum gonadotrophin (PMSG) and human corionic gonadotrophin (hCG ) (i.e. by the use of biostimulation methods to induce receptivity). The methods used were supplementary lighting affecting changes in gonadotrophin releasing hormone $(\mathrm{GnRH})$ release (McNITT, 1992), feeding flush and male presence. Closing off the nest box for a day or more (mother-litter separation; MLS) is also used to stimulate receptivity by delaying nursing. In a study, the nest was closed on day 9 after suckling with no suckling allowed on day 10 and insemination was carried out at $10.00-11.00 \mathrm{~h}$ on day 11 . Immediately thereafter does were allowed to nurse, which resulted in an improvement of fertility bys $20 \%$ (VIRAG et al., 1999). In another test, fertility (94.9 vs 82.3\%) and litter size (10.1 vs 9.3 kits) increased when the nest was closed during day 10 , from 10.00 to $10.00 \mathrm{~h}$ next day, then on day 11 nests were opened for sucklng and immediately followed by receptivity test (taking doe to buck) and insemination. Another study showed a slight non significant improvement in receptivity and fertility rates by omitting one suckling then carrying out artificial insemination (AI) (THEAU-CLEMENT and MERCIER, 1999). The basis of controlled suckling was that the natural nursing behaviour is once per day in the morning (FERGUSON et al., 1997), although HOY (1997) claimed that the doe nurses more than once per day and that mother/ child relations do not exist.

With regard to breeding of does in terms of receptivity or response, it is probably best in the morning and if the doe's nest box is closed off, breeding the doe is achieved before allowing suckling. These two actions avoid the circadian peak of prolactin levels around 1500 to $1900 \mathrm{~h}$ (McNITT, 1992), and the rise in prolactin during and after each suckling, since prolactin has a negative effect on receptivity. When mating, the doe is put with the buck for two services performed by the buck within just a few minutes and the doe then returned to her cage after leaving her with the buck for sometime. Perhaps the evening is better from the buck's perspective, since there is a pulsatile release of $\mathrm{GnRH}$ at about $1 \mathrm{~h}$ frequency and significantly higher level of GnRH release occurs during the evening compared to afternoon (McNITT,1992).

\section{Mating}

Rabbits are induced ovulators, i.e. no regular oestrous cycle exists in rabbit (MAERTENS et al., 1995). The stimulus of mating initiates the ovulation process, due to the surge of GnRH after mating from various hypothalamic areas by physical stimulation of genital areas causing the LH spike which initiates the ovulatory process (McNITT, 1992). With the fall in the level of circulating progesterone, the first wave of follicle maturation begins in late pregnancy, normally on day 29-30 (DIAZ et al., 1987). Ovulation occurs 10-13 h after copulation, whereas, 20 to $25 \%$ fail to ovulate (EL-KELAWY, 1997) which is the major factor in rabbit infertility. Oxytocin level increases in response to mating, and there is a second increase about $5 \mathrm{~h}$, perhaps by uterine and tubal contractions due to second wave of spermatozoa migration (McNITT, 1992).

To maximize production, rebreeding can be carried out at 9 to 10 days and AI could be applied at day 11 post-partum. Such post-partum periods were defined to avoid the negative nutritional balance after lactation or the lactation load (XICATO, 1996), while peak receptivity was noticed at 9 days post-partum (DIAZ et al.,1987). 
In natural mating, when a buck is put in a female's cage, the first act is to mark this new territory with his smell, while the doe tries to eliminate the intruder by immediately attacking him, but if a doe is put in a buck's cage the buck becomes very active sexually and attempts immediate mating, though this is evaded by the female initially. Preparation of a receptive doe for mating takes 20-120 seconds, and the act itself is less than a second, i.e. for servicing it is the doe that should be moved. This is relatively easy, because does are calmer and weigh less than bucks (LEBAS et al., 1986). TEMPLETON (1968) and KANABLE (1977) confirmed that after transfer of the doe to the breeding hutch with the buck, the doe is scared for sometime, then starts to acquaint with the hutch and the male. Successful mating depends on the receptivity of the female. In Cal does, the best post-partum time for presentation to the buck was found to be days 5 and 9 for primparous (day 5 was best) and days 3 and 9 for multiparous (day 9 was best). The follicular growth peaks on days 3, 5, 9 post-partum correspond with periods of maximum sexual activity (DIAZ et al., 1987). The sexually mature doe in heat receives the male after 2 or 3 initial attempts. The libido in the male is so vigorous that it becomes tired if 4 or 5 attempts to mate failed. Hence care should be taken to complete mating process within 4 attempts. A successful mating is recorded from the characteristic wooing sound of the male followed by his falling off the female either backward or in sideways direction (BURDEN, 1972; LEBAS et al., 1986). Some males pull the fur or wool from the shoulder region of the female on unsuccessful mating. REBOLLAR et al. (1992) attributed the failure of mating on day 14 post-partum to low estradiol-17 $\beta\left(\mathrm{E}_{2)}\right.$ levels. The data available on evolution of $\mathrm{E}_{2}$ concentrations during the post-partum period are widely variable and suggest that days 1 and 9 of the post-partum as favourable for insemination (REBOLLAR et al., 1992). A doe in low receptivity refuses to accept the buck. She runs or keeps her head up in the air. Forced mating is waste of time; conception rate is very low if the doe conceives at all. It is better to cull than to force breed does (McCROSKEY, 2000).

Rabbits are often required to conform to an artificial breeding schedule so that chores can be performed on the same day of each week, instead of following the natural cycles of rabbit receptivity. In such cases, does are rebred on day 11 post-partum (pregnancy 31 days plus 11 days= 42). However, does are not in high receptivity on day 11, so AI is used. A dose of 10-25 IU of hCG induces ovulation even in does which are not receptive to the buck (LOPEZ et al., 1993). All the pre-ovulatory follicles do not ovulate, especially in non-oestrous rabbit, due to lack of LH discharge that can be overcomed by injection of hCG (McNITT,1992). Another exogenous hormone used in AI is PMSG, which has benefits and disadvantages. It is recommended to use a low dose (15-20 IU) and only in lactating non-receptive does and in does with reproductive problems. PMSG stimulates an increase in the number of pre-ovulatory follicles. This would lead to an increase in levels of oestrogens and thus to increase sexual behaviour. PMSG also improves receptivity in natural mating, but there are problems of antibody production to PMSG. Further, the use of PMSG may result in infeasibility of selection of does on the basis of low fertility (MAERTENS et al., 1995). However, does receptive at time of insemination were much more fertile than the non receptive does independent of treatment by PMSG and physiological state. Treatment was of no effect on non lactating does (THEAUCLEMENT and LEBAS, 1996). 
McCROSKEY (2000) stated that while using a new buck (about 24 weeks of age), services should be limited to two per week for the first two months. Then, the best frequency of use of the buck is one mating every three days and may be every second day for a while, but an extra rest day may be needed once a week. Bucks can be used once a day for as much as a month in an emergency, but the results may not be good.

\section{Pseudo-pregnancy phenomenon}

When a doe is mated and the mating is not fertile, it happens that the ova are shed, the corpora lutea are formed, the hormones are released by the corpora lutea, the mammary glands are stimulated to activity and may even secrete some milk, the uterus increases in size, the remainder of the reproductive system and the doe will behave as if pregnant, although she is not. This condition continues for 16 to 18 days (LEBAS et al., 1986; SANDFORD, 1996). This condition is known as pseudo-pregnancy, in which. the doe acts as though she is about to give birth to young, i.e. she makes a nest at the end of pseudo-pregnancy, but the nest building may be very slight. Any of such signs as early as the $16^{\text {th }}$ or $17^{\text {th }}$ day after mating (or sometimes quite a few days earlier) may be taken as a fairly reliable signs that the doe has been pseudo-pregnant (LEBAS et al., 1986; SANDFORD, 1996).

During pseudo-pregnancy, the doe may display oestrous behaviour (HAMMOND and MARSHALL, 1925; HUGHES and MYERS, 1966; CAILLOL et al., 1984). FORCADA and ABECIA (1990) described the reaction of the pseudo-pregnant female rabbit (induced by vasectomized bucks) when introduced into the cage of the male as follows: flattening on the floor of the cage, circling, circling and flattening, running away quickly from the male, trying to mount the male and occasionally showed an aggressive behaviour. This occurred during days 0-12 of pseudo-pregnancy. Percentage of receptivity during pseudo-pregnancy was only $10 \%$ (exhibited lordosis) of those does mated with vasectomized bucks, i.e. receptivity was maintained at a low level (CAILLOL et al., 1983). Reappearance of large, steroidogenically active follicles in the ovary occurred on day 6 of pseudo-pregnancy (OSTEEN and MILLS, 1980) and sexual behaviour intensity increased at the end of pseudo-pregnancy (CAILLOL et al., 1984).

After the pseudo-pregnancy period (16-18 days), the corpora lutea of pseudopregnancy degenerate and the doe is highly fertile, and opportunity should be taken to mate her. Some cases of pseudo-pregnancy might be prevented by double mating, i.e. a second mating within at most five hours after the first. A mating later than this will have no effect (LEBAS et al., 1986; SANDFORD, 1996).

\section{Kindling}

Nest making is still the task of the mother rabbits in the small and large scale enterprises (SZENDRÕ et al., 1988). After 20-25 days of pregnancy and under any environmental conditions, the doe builds a nest for the pups from a bedding material which is mostly straws, covered with hair which she pulls from her fur (DENENBERG et al.,1963; VERGA et al., 1978).

The nest straws are aligned lenghtwise in the nest after the doe chopps them up and arranges them. The best nest straw material is barley straw, especially when baled by hay-making equipment which softens it up considerably. 
About $75 \%$ of the does in hutches pull out their own fur or wool, although in cold weather, the female rabbits strive to make good nest bed by pulling hair from their bodies to maintain the adequate temperature. Some of the non pregnant does start pulling off their hair between days 17 and 20, an act termed as false pregnancy (KANABLE, 1977).

The wild doe makes her nest in a cavity hollowed in the earth and deposit plant material and faecal pellets in these nests. Faecal pellets dropped in the nest varied in number from 0 to 25 (mean $8.4 \pm 1.5$ ) during days 4-17 (mean at day 9.6 \pm 0.64 ). No effects were observed on growth or survival rates of presence or absence of pellets in nests. The results showed this to be a normal necessary behaviour of the doe (McNITT and MOODY, 1987).

Most hair pulled was during April-July and the least during August and September. However, monthly changes in hair quantity show similar trend to changes in doe's hair coat (CSONKA and SZENDRÕ, 1984). Quantity of hair and state of moulting are related: in cold weather, does strive to make a good nest, but do not pull so much as to excessively chill themselves. Quantity of hair pulled is independent of litter size. There is a definite relation between quantity of hair and mortality of the young, i.e. more losses are recorded at lower hair quantity, while does pulling out more hair have higher number alive and higher kits gain weight at 21 days (SZENDRÕ and KUSTOS, 1988). This necessitates to check the litter at parturition, to add additional rabbit fur saved from other does, if necessary, and to ensure that there is at least $2.5 \mathrm{~cm}$ bed of straw on bottom and all sides of litter, so that the litter does not touch the sides or bottom of the box. Most of the fur added must be put over the kits and the fur added should not be of raw rabbit fur, but the raw fur should be sterilized by rinsing and covering with water in home pressure cooker and boiling under pressure for 15 minutes. Then, after the water is drained off, the fur is allowed to dry before use.

The pregnant does finally deliver on these beds. Normal deliveries do not require assistance. Parturition usually occurs in the morning. However, it may also occur at other times of the day with apparent exception of a period of several hours before dawn which seems to be reserved for nursing. Parturition is rapid, usually not lasting more than 10 to 15 minutes for the birth of 10 or more kits. It is important that the kits are rapidly expelled, since the vagina of the rabbit is long and the umbilical cord often ruptures in the birth canal. An increase in the duration of parturition even for a few minutes is associated with an increase in stillbirths and in lethargic, non-viable kits (HUDSON et al., 2000). The rapid expulsion of kits is ensured by a large release of oxytocin into the blood stream at this time and by the action of an unusually complex array of strong muscles associated with the doe's vaginal tract (HUDSON et al., 1996). The kits are usually born separated from the placenta and free from membranes. They vigorously start the search for nipples and attempt to suckle while birth is still in progress. The kits are able to cast off any remaining membranes, suckle and survive whether directly attended to by the mother or not (HUDSON et al., 1999). The does frequently lick the kits and avidly consume the placentas. Immediately after giving birth, does leave the kits, close the burrow entrance, and only return to nurse for 3 to 4 minutes once each day. However, just before leaving the nest after nursing, the doe drops a few faecal pellets. It is suggested that such faecal pellets are the basis for microorganism population of the digestive system of the kits (McNITT and MOODY, 
1987). With regards to the kits and nest materials, it is very important that they are not touched at all before the doe is allowed to nurse the kits.

Total parturition time would be 10-14 minutes for a large litter and 5-7 minutes for an average litter (ROMMERS et al., 1999). However, parturition could be induced to allow prompt attention to kindling and to avoid situations make: kindling at night, in cold weather, in does with poor maternal instinct, first time kindling and/or avoids the variability in gestation period (29 to 34 days). Induction of parturition can be practised for does in day 30 or 31 of gestation by placing them on a smooth surface, calmed down, then the hairs around the teats are plucked out with thumb and forefinger. Each of those does is then held in a nest to nurse a group of 5-6 kits of 5-8 days of age, for 3-5 minutes. Finally, massage is applied for 30-60 seconds to the abdomen of the doe with a sterilized hand. The doe is returned to her kindling cage and should kindle in about 3 minutes if it is of 30-31 days pregnant and 4-6 minutes if 32-33 days pregnant. Longer suckling than 3 minutes can lead to no milk left for the new litter, or the doe will become restless and kindle during nursing. This technique was more effective during autumn, winter and spring, but had relatively poor effect during summer. Particularly, this technique is reserved for does that have gone through the day 31 of gestation during cold weather without natural parturition. They are then induced in the evening. Induced does should not eat placentas or lick fluids and require prompt attention to young to prevent suffocation and chilling. The induction method works by stimulation of oxytocin, which is involved in both parturition and milk ejection. Plucking of hairs and nursing stimulate receptors in the teat that send message to the brain's centre for milk ejection and oxytocin release. The massage induces movement of the foetuses and uterus, allowing foetus to come under the effects of the contractions, which help to dilate the cervix and vagina causing more oxytocin release reflexively. Under more powerful contractions, the foetuses are born quickly (GU, 1992).

\section{Nursing}

Suckling: Under natural conditions, nursing usually takes place at night, particularly during the early morning hours before dawn, for first 2 weeks when the kits are confined to the blocked nursery burrow. Kits are attracted to nurse by the suckling pheromone around the nipples and in the milk (McNITT, 1992) and require only seconds to attach to a nipple after the doe's arrival in the nest, although the nipple search time decreases significantly with age (KAPATI et al., 2000). The dependence on odour and certain tactile cues for nursing may explain why newborn rabbits are difficult to hand raise (HUDSON and DISTEL, 1982). This may be the reason in that the kits with no sense of smell, cannot locate the nipples and do not drink milk from a nipple.

Nursing time is between 2.3 and 2.9 minutes, except for the first day (HUDSON and DISTEL, 1982). Within a daily nursing time of 3-4 minutes, dams require an average 5.2 seconds to assume the nursing posture and kits take seconds to contact belly fur and 6.0 seconds to reach and secure a nipple, then kits suckle during the remaining time. The nursing/suckling time is affected by litter size. Doe with smaller litter spends longer time in the nest box than the nursing larger litter. Pups release and switch teats frequently, but their efficiency improves with age. The proportion of nursing time spent in suckling increases from approximately 47 to $72 \%$, during the first 12 days 
(HUDSON and DISTEL, 1983). Average of sucklings/day was estimated as 1.53-1.64 (range between 1 and 6) with duration averaging 210 seconds (SEITZ et al., 1997; SELZER and HOY, 1999). The highest frequency of suckling was in the second week of lactation in which suckling was initiated by the does, since the kits had not left the nest (HOY, 2002). In the third week, suckling frequency decreased, but it again increased in the fourth week.

Suckling behaviour was influenced distinctly by circadian rhythm; $42.6 \%$ of all suckling events took place between 1800 and $2300 \mathrm{~h}$ (SELZER and HOY, 1999). Structured and unstructured cages showed no significant difference in suckling events per day or duration of suckling. Cage size along with suckling time negatively affected frequency of suckling in $24 \mathrm{~h}$, while cage size or structure showed no distinct influence on suckling behaviour (SELZER and HOY, 1999). Similarly, no significant difference was observed between young rabbits with continuous access to the doe, and young allowed access for only a few minutes in the morning or evening (HARKNESS, 1988). However, ROMMERS et al. (1999) reported that kits could consume more milk when does enter the nest more than once per day. The same authors indicated that does not given free access had lighter litter mass at day 21 and weaning and post-weaning mortality was much higher in closed box litter (14.9\%) than in free one (8.4). HOY et al. (2000) and HOY (2002) confirmed that mother-litter separation during night can influence species specific nursing behaviour and may lead to lower weaning weights of pups. However, HUDSON et al. (2000) advised to restrict does access to the nest to just one regularly timed visit a day. Rabbits do not produce colostrum, hence kits receive antimicrobial protection from the fatty acids in the doe's milk (McNITT and MOODY, 1992). Milk production increases until end of the third week with peak yield of $300 \mathrm{~g} / \mathrm{d}$ (ROMMERS et al., 1999). At the same time, milk production draws down the doe's energy reserves. Fat content also decreases, throughout the lactation period (MILISITS et al., 1999). Addition of vegetable oil to the doe's diet leads to high kit mass, probably by increasing milk production rather than by a change in milk composition (ROMMERS et al., 1999), increasing the unsaturated fatty acid content of milk and decreasing the medium chain fatty acids ( $\mathrm{C} 8$ to $\mathrm{C} 15$ ) (FORTUNLAMOTHE, 1997): the energy content of milk do not change. Environmental temperature effect on milk yield was highly significant, while its effect on milk composition was negligible (PAPP et al., 1999). The summer milk yield was significantly lower than in the other seasons (AYYAT et al., 1995; AYYAT and MARAI, 1998). Milk yield increased with nipple number (N), while individual milk consumption decreases with the increase in litter size and accordingly daily gain of a small litter is always better than large litter size, although $10 \mathrm{~N}$ was $8 \%$ better than $8 \mathrm{~N}$ (MOHAMED and SZENDRÕ, 1992). From another point of view, the amount of milk intake of kits varies considerably due to the competition with litter mates. If the number of nipples is more than litter size, some of the kits have a chance to suckle two nipples, and the pups spend more time to switch teats searching for the most productive ones, while if the litter size is more than the number of nipples, it is not possible for all kits to reach a nipple at the same time and they have to suckle faster and the competition among them becomes more fierce (MOHAMED and SZENDRÕ, 1992). However, litter size should not be restricted to the number of the teats, since the kits move around all the time while nursing. 
A litter of 10 is a good size. Some kits may be moved from large litters to smaller litters in order to try to avoid litters over 12 kits. The largest and smallest kits of a litter should not be killed as some people recommend (McCROSKEY, 2000).

Fostering young: Fostering is the art of transferring offspring from one doe to another and is accomplished by transferring the young into the nest of the foster doe. When a doe dies or produces the first litter, fostering may be of use, but if she dies from disease the young should not be fostered. The maximum activity of the mammary glands is achieved by fostering only after few days. Fostering should be carried out within the first ten days after birth. However, it may be delayed to the age of three weeks, although at this late age it will not always be successful. It is advisable to remove the doe for a short period and then give her some tidbit when she is returned to her hutch. Care should also be taken to observe that she accepts the youngsters and does not attack them. When a doe is being used as a foster for the first time or her maternal characteristics are uncertain, it may refuse access to her nest for an hour or two.

Does acceptance of her own litter and rejection and destruction of a strange litter are primarily dependent on olfactory cues. Strange young may be attacked and killed by the offended doe, unless characteristic odours are masked by perfume or the caretaker distributes a new scent to a fostered litter. Attacking young may occur even if the young are from the same territorial or social grouping as the host doe, although this may not be a problem in domestic rabbits; since young kits can be readily fostered to a different doe with no special handling precautions. If a buck is present when a strange litter is introduced into a foster doe's cage, that buck may mark or chin the young and thereby protect them from further doe aggression. In an established doe and litter group, the doe's odour guides and groups the young (MYKYTOWYCZ and GAMBALE, 1969; MYKYTOWYCZ and DUDZINSKI, 1972). However, the true value of the foster mother cannot be assessed unless she is left with a full-sized litter (SANDFORD, 1996).

\section{Maternal anomalies}

A doe may proceed to eat the placenta or may inadvertently eat parts of the young immediately following kindling, or may scatter the young at birth or eat them. Similarly, a doe may start eating some kits when licking away the blood from any wounds so caused. Others, although very rare, may attack and kill their young at a week or more old. Rats also may kill and eat parts of some young rabbits; the damage being wrongly attributed to the doe. Some does are temporarily very vicious, either to their young towards the end of weaning or to the attendant. The frightened doe may some time injure/kill one or more of her young during her panic. The doe that is constipated becomes feverish and develops an abnormal appetite, and in this condition may kill and eat her young. Undue handling or excitement at pregnancy may also cause such destruction. All cases rarely occur in a well managed rabbitry. The abnormal behaviour in the doe may also be due to disturbance, hormonal imbalance and/or environmental stress (DENENBERG et al., 1963; HAFEZ, 1975; SANDFORD and WOODGATE, 1980; EMEASH and KAROUSA, 1994; SANDFORD, 1996). Another causes may be nervousness, poor body condition, lack of milk, poor hygiene, presence of other animals, poor stockman care, environmental changes, heat, over crowding, lack of experience, moulting, genetic factors (VERGA, 1992), nutritional 
deficiencies or lack of sufficient food and fibre in the diet (KAMEL et al., 1993) and inadequate drinking water either in quality or quantity. Other maternal anomalies may include false pregnancy (presumed), embryo reabsorption, abortion, failure to build the nest, parturition outside of nest, late pulling fur, sitting in the box, defecating and/or urinating in the box, being over-excitable or any other abnormal behaviour regarding the nest. A valuable doe that destroys her first litter should be given another chance, but in case she continues the same practice with subsequent litters she should be sold for meat (ASHBROOK, 1955).

Eating part or all one or more pups is defined as cannibalism. Cannibalism in rabbits may be associated with dead or deformed young. Such phenomenon may be due to a hyperexcitable primparous doe, placentophagy, environmental disturbance or a low energy diet (HARKNESS and WAGNER, 1989).

Applying good management programs, as well as, change of place, gentle handling of the stressed dams, correcting nutritional deficiencies and inadequate drinking water and provision of adequate amount of straw may well eliminate stress, correct behavioural disorders and certain types of maternal anomalies which appear to be not under the control of hormonal or genetic factors. From another point of view, any doe that is causing a problem to the kits must be closed out, except for morning nursing time and feeding time (about 10 minutes).

\section{Viciousness and Trichophagy}

Vicious rabbit attack all who attempt to handle it. Viciousness should not be confused with nervousness. In the former, an animal may attack a stranger, or a doe with a litter may attack a breeder who attempts to look into the nest due to its strongly developed maternal instinct. Viciousness is usually the result of rough handling which may also cause nervousness of rabbits, although it may be due to other factors. The breeds vary greatly in this respect and while some are very docile, some others are timid rather than docile and the other some tend towards viciousness. In these latter breeds or strains, the animal that continues to be vicious should be eliminated, unless the animal is required for some particular purpose (SANDFORD, 1996). Such animals should be separated to prevent biting. However, very seldom biting occurs before 12 weeks of age which is the normal end of fattening period (HEIL, 1997). Between does, fighting is not as severe as between bucks and the fight will stop as soon as one doe admits defeat. However, when fighting, the parts of the enemy being attacked are mainly the head and rump areas. An attacking doe often tries to bite handler who attempts to reach into her cage. However, such doe usually, is one of the best mothers with good nest making, good caring for the young and very protective. In such case, it is best to soothe the doe before reaching for any of the kits, by patting her on the head.

In trichophagy or fur-eating, the animals eat other's fur and end up with bare backs and flanks. The causes may be unbalanced rations, behavioural problems, unsuitable environment, inadequate lighting, overpopulation, genetics and so forth (LEBAS et al., 1986).

\section{Feeding and Drinking:}

\section{Newborns}

PRUD'HON (1975) and LEBAS et al. (1986) found that a doe feeds her young nearly once every $24 \mathrm{~h}$ for a month. Suckling lasts only 2-3 minutes. If there is not enough 
milk, the young try to feed every time the doe enters the nest box, but she holds back her milk. However, suckling alone does not provoke secretion of oxytocin, but the mother must has the desire to nurse. From the third week of life, young rabbit begin to move about taking few grams of mother's milk and a little drinking water if available. In few days, the intake of solid feed of that of the doe and water exceed the milk intake. The small size of young allows them to slip easily into forage racks or dry feed hoppers, but the feeding pattern of newborn rabbits is imposed by the dam. However, the feeding troughs must be designed to keep newborns out. The feeding behaviour of the young during the mentioned period changes remarkably. The young rabbit goes from a nearly single suckling a day to a large number of alternating solid and liquid feeds distributed irregularly throughout the day. The number of solid meals stablizes up to 12 weeks and tends to decrease slightly thereafter. The total time spent in feeding every $24 \mathrm{~h}$ exceeds $3 \mathrm{~h}$ at 6 weeks of age, then drops off rapidly to less than $2 \mathrm{~h}$. Caecotrophy first starts to function in young rabbits (domesticated or wild) at the age of about 3 weeks, i.e. when they start eating solid feed in addition to mother's milk (LEBAS et al., 1986). HUDSON et al. (1999) suggested that raising kits in nests that contain plant material and faecal pellets may improve growth and reduce mortality during the critical post-weaning period. It is suggested to drop a few feed pellets into the nest box beginning on about day 15 of lactation so that the young can start to nibble on the doe's feed. This serves the function of creep feeding without the use of special equipment (McCROSKEY, 2000). The young rabbit picks up the necessary digestive organisms through the doe ( through contacting the caecotrophs before pulling fur, as well as, before licking off the kits) and through licking during suckling and also during licking themselves and each other.

\section{Mature animals}

Rabbits eat and drink at any time during the 24 h (LEBAS et al., 1986; HOY, 2000), though they tend to feed nocturnally (LEBAS et al., 1986). The rabbit can be very choosy for the type and quality of feed, with a preference for pelleted feeds, sweet and fresh juicy green feeds, while it avoids meal or porridge feeds. Rabbits fed free choice spend $61.3 \%$ of the feeding time during night and only about $38.7 \%$ of the time during daylight hours (ROMMERS et al., 1999).

KROHN et al. (1999) found that feeding the laboratory rabbits at $14.00 \mathrm{~h}$ reduced abnormal behaviour during the dark period compared to feeding at $08.00 \mathrm{~h}$. The same authors confirmed that the welfare for caged rabbits can be improved by feeding the animals in the afternoon rather than in the morning. As the rabbit grows older, the nocturnal nature of its feeding habits become more pronounced, while the number of feeds during light periods drops and the morning feeding rest tends to lengthen. The feed intake duration values were $9 \%$ from 8.00 to $13.00 \mathrm{~h}, 17 \%$ from 13.00 to $18.00 \mathrm{~h}$ and $74 \%$ (reaching $82 \%$ in summer) from 18.00 to $8.00 \mathrm{~h}$ (MARCELLA and AUGUSTO, 1988). However, intake of each of solid and liquid fluctuates over a $24 \mathrm{~h}$ period. More of both liquid and solid feeds is consumed in the dark than in the light. Intake in experimental hutches is very high just before the lights are switched off. When a doe is both pregnant and lactating, she eats the same amounts of feed as a doe that is lactating only (LEBAS, 1975). However, the wild rabbit is known to feed at dawn and dusk (MYKYTOWYCZ, 1958). The feeding habits of wild rabbits are even more nocturnal than those of domesticated rabbits. 
The straw-eating is significantly influenced by feeding pattern. In that respect, the young kits and the does should have daily access of straw to nibble on. BERCHICHE et al. (1996) mentioned that chewing straw was almost twice as effective as mechanically prepared straw incorporated into the feed. Further, the rabbits enjoy the supplementary straw about midday, while their normal eating time for consuming large amounts of pelleted feed is in the evening. Ten to $15 \mathrm{~g}$ of straw (wheat straw, barley straw or strong grass straw such as canary grass) per cage of young rabbits and replacement doe, provides the necessary supplementary fibre component to their diet, as well as, for making nests by the does. Caecal digestion of rabbits can break down some of the complex oligosaccharides which are the structural components of the straw (McCROSKEY, 2000).

With regard to caecotrophy phenomenon, PROTO (1980) and LEBAS et al. (1986) observed that the colon produces two types of excrements: hard and soft (caecotrophs). The hard pellets are expelled, but the soft pellets are recovered by the rabbit directly upon being expelled from the anus, by twisting itself round, sucking in those pellets as they emerge from the anus, then chewing each mouthful of caecotrophs 40 to 60 times for 15 to 60 seconds. The rabbit can retrieve the soft pellets easily, even from a mere floor. The soft pellets follow the same digestive process as normal feed. Half of the soft pellets consists of imperfectly broken-down food residue that escape gastric digestion and half of bacteria (9.56 million to 2.7 billion micro-organisms in $1 \mathrm{~g}$ of caecotrophs). An appreciable amount of high value proteins and water soluble vitamins are also available, showing that the practice of caecotrophy has a certain nutritional value, although it ceases when the rabbit is sick (ROMMERS et al, 1999). The time of eating corresponds closely with the time of hard faeces excretion, while the time of lowest feed intake correspond with the caecotrophy period, which is mainly in the morning from 04.00 to $12.00 \mathrm{~h}$, with perhaps an additional period at 22.00 to $24.00 \mathrm{~h}$, for post-weaned young rabbits. For adults, the caecotrophy period is about 08.00 to 14.00 h each day (BELLIER et al., 1995). Caecotrophy means that feeds are suitable for the rabbits, while digestive problems are expected when rabbit rejects feeding on caecotrophs (McCROSKEY, 2000).

The feeding behaviour of rabbit is influenced by many exogenous or endogenous factors. Among these, a prominent role is ascribed to ambient temperature and photoperiod (MARCELLA and AUGUSTO, 1988). The laboratory tests on growing rabbits showed that at temperatures between 5 and $30^{\circ} \mathrm{C}$, intake of pelleted feed dropped from 180 to $120 \mathrm{~g}$ and water intake rose from 330 to $390 \mathrm{~g}$ a day. Particularly, the number of solid meals eaten in $24 \mathrm{~h}$ dropped from 37 solid feeds at $10^{\circ} \mathrm{C}$ to only 27 at $30^{\circ} \mathrm{C}$ and the amount eaten in each meal dropped from $5.7 \mathrm{~g}$ at 10 to $20^{\circ} \mathrm{C}$ to $4.4 \mathrm{~g}$ at $30^{\circ} \mathrm{C}$, while the water intake went up from 11.4 to $16.2 \mathrm{~g}$ between 10 and $30^{\circ} \mathrm{C}$. Feeding behaviour of growing rabbits is also influenced by season, but variations are clearly evident only in summer, when a significant decrease in feed intake takes place, that negatively affects weight gain. On the contrary, in winter ingestion level increases resulting in poor feed conversion. The seasonal effect was also observed during the night hours; the animals consumed during the night hours $82 \%$ of the diet in summer and consumed $74 \%$ in winter season. The rabbits are more active during darkness mainly in relation to grazing (MYKYTOWYCZ and ROWLEY, 1958). 
More than $60 \%$ of water intake occurs at night and after intake of dry feeds. Daily water intake is about 2.0 to 2.5 times the amount of dry matter intake. When dry feeds were fed without water, a decrease in feed intake occurred. Limiting drinking time to 10 minutes every two days, resulted in a decreased feed intake by 14 to $24 \%$. Growth is also retarded and body weight decreases drastically. When allowing drinking water for 10 minutes per day no significant effect on feed intake or growth rate was detected (ROMMERS et al., 1999). Such time would be considered as the minimum drinking requirement for rabbits using water troughs, while rabbits drinking from water nipples require several hours (McCROSKEY, 2000). Drinking water offered either through nipples or through clay troughs, showed favourable effects on growth, carcass weight and social behaviour of rabbits (El-MAHDY and KAROUSA, 1995). However, aggressive behaviour was greater in rabbits on nipple drinkers than in those on troughs. During extreme cold $\left(9^{\circ} \mathrm{C}\right.$ and below), water troughs can be taken away at night and refilled with warm water in the morning. However, growth was slower in cold than in the milder conditions (McCROSKEY, 2000).

\section{Conclusions}

Intensification of production may lessen welfare of the animal through pushing the animal hard by the different methods of production. In addition, the animal looses his freedom to display some of the normal patterns of behaviour, whereas developing some managemental procedures that alleviate such phenomena are useful.

ASHBROOK, F.G.:

\section{References}

How to Raise Rabbits for Food and Fur. Orange Judd Puplishing Company, New York, USA. (1955), 165

AYYAT, M.S.; MARAI, I.F.M.:

Evaluation of application of the intensive rabbit production system under the sub-tropical conditions of Egypt. World Rabbit Sci. 6 (1998), 213-217

AYYAT, M.S.; MARAI, I.F.M.; EL-SAYIAD, GH.A.:

Genetic and non-genetic factors affecting milk production and pre-weaning litter traits of New Zealand White does, under Egyptian conditions. World Rabbit Sci. 3 (1995), 119-124

BELLIER, R.; GIDENNE, T.; VERNAY, M.; COLIN, M.:

In vivo study of circadian variations of the cecal fermentation pattern in postweaned and adult rabbits. J. Anim. Sci. 73 (1995), 128-135

BERCHICHE, M.; LEBAS, F.; LOUNAOCI,G.; KADI, S.A.:

Feeding of local population of rabbits: Effect of straw addition to low fibre pelleted diets on digestibility, growth performance and slaughter yield. $6^{\text {th }}$ World Rabbit Congr., France 1 (1996), 89-92

BEREPUBO, N.A.; NODU, M.B.; MONSI, A.; AMADI, E.N.:

Reproductive response of prepubertal female rabbits to nphotoperiod and/ or male presence. World Rabbit Sci. 1 (1993), 83-87

BEYER, C.; MCDONALD, P.:

Hormonal control of sexual behaviour in the female rabbit. Advanced Reprod. Physiol. 6 (1973), 185214

BEYER, C.; RIVAUD, N.:

Sexual behaviour in pregnant and lactating domestic rabbits. Physiol. and Behav. 4 (1969), 753-757

BURDEN, B.H.:

Goals in Rabbit Raising. Hullbarton, Ontario, Canada. (1972)

CAILLOL, M.; DAUPHIN-VILLEMANT, C.; MARTINET, L.:

Oestrous behaviour and circulating progesterone and oestrogen levels during pseudo-pregnancy in the domestic rabbit. J. Reprod. and Fertil. 69 (1983), 179-186

CAILLOL, M.; SOLARI, A.; LEFEVRE, J.: 
Changes in steroid concentrations in follicular and sexual behaviour during pseudo-pregnancy in the rabbit. Reprod. and Nut. Dev. 24 (1984), 95-105

CHALLIS, J.R.G.; RYAN, D.J.; DAVIES, I.J.:

The concentration of progesterone, estrone and estradiol-17 $\beta$ in the plasma of pregnant rabbits. Endocrinology 93 (1974), 971-976

CSONKA, I.; SZENDRÕ, ZS.:

The effect of season on the productive performance of rabbit. Reports of RCPN (1984), 311-317 (Cited by ZSENDRÕ and KUSTOS, 1988).

CUDNOVSKII, L.A.O.:

A method of determining sexual activity in rabbits. Krolikovodsvo I Zverovodsvo 10 (1957), 37-38

DENENBERG,V.H.; ZARROW, M.X.; KALBERER, W.D.; FAROOQ, A.:

Maternal behaviour in the rabbit. Effects of environment variation. Nature 197 (1963) 4863, 161-162

DIAZ, P.; GOSALVEZ; L.F.: RODRIGUEZ, J.M.:

Sexual behaviour in the post-partum period of domestic rabbits. Anim. Reprod. Sci. 17 (1988), 251-257

DIAZ, P.; RODRIGUEZ, J.M.; GOSALVEZ, L.F.; ROMAN, M.R.:

Cyclic ovarian activity in post partum rabbits. J. of Appl. Rabbit Res. 10 (1987), 122-125

EL-KELAWY, H..M.:

Effects of hCG injection and breed on reproductive performance of rabbits, under Egyptian conditions. World Rabbit Sci. 5 (1997), 61-64

EL-MAHDY, M.R.; KAROUSA, M.M.:

Social behaviour, growth performance and carcass traits in growing New Zealand White rabbits as affected by iodine-treated water, water source and watering system. Egyptian J. of Rabbit Sci. 5 (1995), 65-76

ELSAESSER, F.:

Effects of active immunization against oestradiol-17 $\beta$, testosterone or progesterone on receptivity in the female rabbit and evaluation of specificity. J. of Reprod. and Fertil. 58 (1980), 213-218

EMEASH, H.H.; KAROUSA M.M.:

The influence of some managerial programmes on maternal anomalies and pup's performance in White New Zealand rabbit. Proc. of $1^{\text {st }}$ International Conf. on Rabbit Prod. in Hot Climates, Cairo, Egypt (1994), 425-429

FERGUSON, F.A.; LUKEFAHR, S.D.; MCNITT, J.J.:

A technical note on artificial feeding of rabbit kits weaned at 14 days. World Rabbit Sci. 5 (1997), 6570

FERRANTE, V.; VERGA, M.; CANALI, E.; MATTIELO, S.:

Rabbit kept in cages and in floor pens. Reactions in the open field tests. J. of Appl. Rabbit Res. 15 (1992), 700-707

FINZI, A.; MARGARET, R.; CALABRESE, A.:

A two-floor cage for rabbit welfare. Proc. of $6^{\text {th }}$ World Rabbit Congr. Toulouse, France 2 (1996), 423424

FORCADA, F.; ABECIA, J.A.:

Circulating progesterone levels, ovulation rate and sexual behaviour in rabbits during pseudo-pregnancy induced by vasectomized males and HCG injection. J. of Appl. Rabbit Res. 13 (1990), 74-79

FORTUN-LAMOTHE, L.:

Effects of dietary fat on reproductive performance of rabbit does: A review. World Rabbit Sci. 5 (1997), 33-38

GOODRICH, B.S.; MYKYTOWYCZ, R.:

Individual and sex differences in the chemical composition of pheromone like substances from the skin

GU, Z.: glands of the rabbit (Oryctolagus cuniculus). J. of Mammalogy 53 (1972), 540- 548

Study on parturition inducing technique in rabbits. J. of Appl. Rabbit Res. 15 (1992), 575-582
HAFEZ, F.S.E.:

Maternal behaviour in mouse and rabbit and the question of generality. In: Behaviour of Domestic Animals. $3^{\text {rd }}$ Edition, Tindal, Baillier and London. (1975)

HAMMOND, J.; MARSHALL, F.:

Reproduction in the Rabbit. Oliver and Boyd, Edinburgh. (1925)

HARKNESS, J.E.:

Rabbit behaviour as related to environmental stress. J. of Appl. Rabbit Res. 11 (1988), 227236

HARKNESS, J.E.; WAGNER, J.E.:

The Biology and Medicine of Rabbits and Rodents. $3^{\text {rd }}$ Edition, Lea and Febiger.Philedelphia, London. (1989)

HEATH, E.: 
Sexual and related territorial behaviour in the laboratory rabbit (Oryctolagus cuniculus). Lab. Anim. HEIL , G.: Sci. 22 (1972), 684-691

Genetic influences on the development of aggressive behaviour among male domestic rabbits kept together (Abstract). World Rabbit Sci. 5 (1997), 88

HILLARD, J.; SPIES, H.G.; SAWYERC, H.:

Cholesterol storage and progestin secretion during pregnancy and pseudo-pregnancy in the rabbit. HOY, ST.: Endocrinology 82 (1968), 157-165

Use of infrared-video technique in behavioural investigations in rabbits (Abstract). World Rabbit Sci. 5 (1997), 87

HOY, ST.:

The use of infrared video technique and computer supported analysis in investigatios of rabbit behaviour. Proc. of the $7^{\text {th }}$ World Rabbit Congr., Valencia, Spain B (2000), 531-536

HOY, ST.:

Nursing behaviour in wild and domestic rabbits. Proc. of $14^{\text {th }}$ Hungarian Confer. on Rabbit Prod. (2002),23-35

HOY, ST.; SEITZ, K.; SELZER, D.; SCHUDDEMAGA, M.:

Nursing behaviour of domesticated and wild rabbit does under different keeping conditions. Proc.of the $7^{\text {th }}$ World Rabbit Congr. Valencia, Spain B (2000), 537-543

HUDSON, R.; DISTEL, H.:

The pattern of behaviour in rabbit pups in the nest. Behaviour 79 (1982), 255-271

HUDSON, R.; DISTEL, H.:

Nipple location in newborn rabbits: Behavioural evidence for pheromonal guidance. Behaviour 85 (1983), 260-275

HUDSON, R.; GONZALEZ-MARISCAL, G.; BEYER, C.:

Chin marking behaviours, sexual receptivity, and pheromone emission in steriod-treated, ovariectomized rabbits. Hormones and Behav. 24 (1990), 1-13

HUDSON, R.; SCHAAL, B.; BILKO, A.:

Transmition of olfactory information from mother to young in the European rabbit. In Mammalian Social Learning: Comparative and Ecological Perspectives. Eds. H.O.BOX and K.R. GIBSON. Cambridge Unversity Press (1999),141-157

HUDSON, R.; SCHAAL, B.; BILKO, A.; ALTBACKER, V.:

Just three minutes a day: The behaviour of young rabbits viewed in the context of limited maternal care. Proc. of the $6^{\text {th }}$ World Rabbit Congr. Toulouse, France 2 (1996), 395-403

HUDSON, R.; SCHAAL, B.; MARTTINEZ-GOMEZ, M.; DISTE, H.:

Mother-young relatios in the Euroepean rabbit: physiological and behavioural locks and keys. PanAmerican Rabbit Sci. Newsletter 5 (2000), 3-8

HUGHES, L.; MYERS K.:

Behavioural cycles during pseudopregnancy in confined populations of domestic rabbits and their relation to the histology of the female reproductive tract. Australian J. of Zoology 14 (1966), 173-183

KAMEL, M.M.; MYERS, L.J.; CUMMINS, K.A.: Influence of dietary fibre on maternal behaviour in rabbits. Vetr. Med. J., Giza, Egypt 41 (1993), 23-29

KANABLE, ANN.:

Raising Rabbits. Rodale Press, Emmaus PA, USA. (1977)

KARPATI, K.; CHERITAH, L.; BILKA, A.:

Nipple switch and nipple-search behaviour factors contributing to the efficiency of suckling. KLEIN, M. Proceedings of the $7^{\text {th }}$ World Rabbit Congr., Valencia, Spain B (2000), 519-524

Aspects biologiques del' instinct reproducteur dan le comportement des mamiferes. In L'instinct dans le Comportement des Animaux et de L'homme. Paris, Masson et Cie. Editeurs (1956), 287-339

KROHN, TC.; RITSKES-HOITINGA, J.; SVENDSEN ,P.:

The effects of feeding and housing on the behaviour of the laboratory rabbit. Lab. Anim. 33 (1999), 101-107

LEBAS, F.:

Le lapin de Chair, ses Besoins Nutritionnels et son Alimentation Pratique. Edition Revue et Completee. Paris, (1975), I.T.A.V.I.

LEBAS, F.; COUDERT, P.; ROUVIER, R.; ROCHAMBEAU, H.DE.:

The Rabbit Husbandry, Health and Production. FAO Anim. Prod. and Health Series, Rome. (1986)

LEHMAN, M.: 
Interference of a restricted environment as found in battery cages, with normal behaviour of young fattening rabbits. In Rabbit production systems including welfare.(Ed. T. AUXILIA). Commission of the European Communities. Brussels (1987), 257-269

LEHMAN, M.:

Social behaviour in young domestic rabbit under semi-natural conditions. J. of Appl. Anim. Behav. Sci. 32 (1991), 269-292

LOPEZ, M.; FORCADA, F.; RODRIGUEZ, J.A.; MARTIN, M.; ZARAGAZA L.:

Emberyo recovery under anaesthesia after hCG or GnRH treatments in the rabbits and survival when a reduced number of embryos is transferred. World Rabbit Sci. 1 (1993), 127-132

MAERTENS, L.; LUZI, F.; GRILLI, G.:

Effects of PMSG induced oestrus on the performance of rabbit does: A review. World Rabbit Sci. 3 (1995), 191-199

MARCELLA, B.; AUGUSTO, G.:

Some observations on feeding behaviour of growing rabbits. Proc. of the $4^{\text {Th }}$ World Rabbit Congr. 3 (1988), 79-86

McCROSKEY, R.A.:

Behaviour of the rabbit. (A Review). Pan-Am. Rabbit Sci. Newsletter 5 (2000), 18-31

McNITT, J.I.:

Endocrinological approaches for commercial rabbit production. J. of Appl. Rabbit Res. 15 (1992), 364397

McNITT, J.I.; MOODY, G.L.JR.:

Nest box behavior of the domestic rabbit. J. of Appl. Rabbit Res. 10 (1987), 159-162

McNITT, J.I.; MOODY, G.L.JR.:

A method for weaning kits at 14 days. J. of Appl. Rabbit Res. 15 (1992), 661-665

MILISITS, G.; ROMVARI, R.; DALLE ZOTTE, A.; SZENDRÕ, ZS.:

In vivo estimation of changes in body fat content of lactating does using X-ray computer tomography (Abstract). World Rabbit Sci. 7 (1999), 151- 154

MOHAMED, M.M.A.; SZENDRÕ, ZS.:

Studies on nursing and milk production of does and milk intake and suckling behaviour of their kits. J. of Appl. Rabbit Res. 15 (1992), 708-716

MORET, B.:

Comportement d'oestrus chez la lapine. Cuniculture 7 (1980), 159-161

MORISSE, J.P.:

La protezione animale, come e perché. Rivista di Coniglicoltura 6 (1999), 9-14

MORISSE, J.P.; MAURICE, R.:

Welfare and the intensive production of rabbits. Revue - Office international des épizooties 13 (1994), $143-152$

MORISSE, J.P.; MAURICE, R.:

Influence of stocking density or group size on behaviour of fattening rabbits kept under intensive conditions. Appl. Anim. Behav. Sci. 4 (1997), 351-357

MYKYTOWYCZ, R.:

Social behavioural of an experimental colony of wild rabbits (Oryctolagus cuniculus L.). 1. Establishment of the colony. CSIRO Wildife Res. 3 (1958), 7-25

MYKYTOWYCZ, R.:

Territorial marking by rabbits. Sci. Am. 218 (1968), 116-126

MYKYTOWYCZ, R.; DUDZINSKI, M.L.:

Aggressive and protective behaviour of adult rabbits (Oryctolagus cuniculus L.) towards juveniles. Behaviour 43 (1972), 96-120

MYKYTOWYCZ, R.; GAMBALE, S.:

The distribution of dung hills and the behaviour of free-living wild rabbits (Oryctolagus cuniculus L.) on them. Forma et Functio 1 (1969), 333-349

MYKYTOWYCZ, R.; ROWLEY, I.:

Continuous observations of the activity of the wild rabbits (Oryctolagous cuniculus L.), during 24 hour periods. C.S.I.R.O. Wildife Res. (1958),26-31

NICOSIA, S.V.; EVANGELISTA, I.; BATTA, S.K.:

Rabbit ovarian follicles. 1. Isolation technique and characterization at different stages of development. Biology of Reprod. 13 (1975), 423-447

OSTEEN, G.K.; MILLS, T.M.:

Changes in the size, distribution and steroid content of rabbit ovarian follicles during early pseudopregnancy. Biology of Reprod. 22 (1980), 1040-1046

PAPP, Z.; KUSTOS, K.; SZENDRÕ, ZS.: 
The effect of environmental temperature and restricted feeding on production in rabbit does. World Rabbit Sci. 7 (1999), 186

PERRIER, G.; SURDEAU, Ph.; DIB, B.; PLASSIER, J.L.:

Etude comparee de deux rythmes de reproduction chez la lapine. Journées De La Recherche Cunicole, Paris, Vol. 3 Commun. no. 3 (1982)

PLA, M.:

Modelos Biologicos de Caracteres Reproductivos en el Conejo de Carne. ETSI Agronomos. Valencia, PROTO, V.: Spain. (1984)

Alimentazione del coniglio da carne. Rivista di Coniglicoltura 17 (1980), 17-32

PRUD'HON, M.:

Lecomportement alimentaire [du lapin] depend beaucoup de l'abreuvement. Elevage (special number): Une prodction d'avenir- Le lapin (1975), 55-59

REBOLLAR, P.G.; UBILLA, E.; ALVARINOO, J.M.R.; ILLERA, J.G.; SILVAN G.: Influence del nivel de receptividad sexual sobre el estradiol plasmatico y la respuesta ovulatoria durante el postparto en la coneja. Rev. Esp. Fisiol 48 (1992), 13-18

ROMMERS, J.M.; KEMP, B.; MEIJERHOF, R.; NOORDHUIZEN, J.P.T.M.: Rearing management of rabbit does: A review. World Rabbit Sci. 7 (1999), 125-138

SANDFORD, J.C: The Domestic Rabbit. 5th Edition. Blackwell Science Ltd, Oxford. U.K. (1996)

SANDFORD, J.C.; WOODGATE, F.G.: The Domestic Rabbit. 3rd Edition, Granada, London, Toronto, Sydney, NewYork. (1980)

SEITZ, K.; GUTKOSKI, S.; LANG, K.; HOY S.: Investigations on suckling behaviour in rabbits. World Rabbit Sci. 5 (1997), 130

SELZER, D.; HOY, ST.:

Suckling behaviour and doe-litter relationship of different rabbit breeds in traditional houing (Abstract). World Rabbit Sci. 7 (1999), 122

STOUFFLET, I.; CAILLOL, M.:

Relation between circulating sex steriod concentrations and sexual behaviour during pregnancy and postpartum in the domestic rabbit. J. of Reprod. and Fertil. 82 (1988), 209-218

SURDEAU, PH.; PERRIER, G.; PLASSIER, J.L.:

Response biologique des lapines adoptant differents rythmes de reproduction. Journées De La Recherche Cunicole, Paris, Commun. no.4. (1982)

SZENDRÕ, ZS.; KUSTOS, K.:

The relationship between nest-making behaviour of the rabbit doe and litter performance. J. of Appl. Rabbit Res. 11 (1988), 247-248

SZENDRÕ, ZS.; KUSTOS, K.; EL-DIN, S.S.:

Hair pull of rabbit does and its relationship with their rearing ability. Proc. of the $4^{\text {th }}$ World Rabbit Congr. 1 (1988), 173-181

TEMPLETON, S.:

Domestic Rabbit Production. The Interstate Printers and Publishers, INC Danvilla, Illinos. (1968)

THEAU-CLEMENT, M.; LEBAS, F.:

Effect of a systematic PMSG treatment 48 hours before artificial insemination on the productive performance of rabbit does. World Rabbit Sci. 4 (1996), 47-56

THEAU-CLEMENT, M.; MERCIER, P.:

Effect of a 24 hour doe-litter separation on rabbit doe reproductive performance and growth of the young. World Rabbit Sci. 7 (1999), 177-179

TORRES LOZANO, C.; PLA, M.; GARCIA, F.:

Sovapposizione tra gestazione e lattazione nella coniglia. Rivista di Coniglicoltura 24 (1987), 37-39

UBILLA, E.; REBOLLAR, P.G.:

A study on the evolution of sexual receptivity and plasma Estradiol-17B levels throughout the lactation period, in rabbits. $1^{\text {st }}$ International Confer. on Rabbit Prod. in Hot Climates. Cairo, Egypt (1994), 377 381

VERGA, M.:

Some characteristics of rabbit behaviour and their relationship with husbandry systems. J. of Appl.

VERGA, M.: Rabbit Res. 15 (1992), 55-63

Troppo stress fa male ai conigli. Rivista di Coniglicoltura 6 (1997), 13-19

VERGA, M.; DELL'ORTO, V.; CARENZI, C.:

A general review and survey of maternal behaviour in the rabbit. Appl. Anim. Ethology 4 (1978), 235252

VIRAG, GY.; KUSTOS, K.; SZABO, L.: 
Effect of 48 hours doe-litter separation on rabbit doe's reproductive performance and offspring's growth. World Rabbit Sci. 7 (1999), 155-159

XICATO, G.:

Nutrition of lactating does. $6^{\text {th }}$ World Rabbit Congr. Toulouse, France 1 (1996), 29-47

YASCHINE, T.; MENA, F.; BEYER, C.:

Gonadal hormones and mounting behaviour in the female rabbit. Am. J. of Physiol. 213 (1967), 867873

Received: 2002-11-18

Accepted: 2003-06-12

Author's addresses

Prof. Dr. FAYEZ M. MARAI

Department of Animal Production, Faculty of Agriculture,

Zagazig University, Zagazig, Egypt

Prof. Dr. A. A. RASHWAN

Department of Animal Wealth, Institute of Efficient Productivity,

Zagazig University, Zagazig, Egypt 